\title{
Clinico-Demographic Profile of Febrile Seizure and Its Association With Iron Deficiency
}

\section{Shyama Birua, Suman Sarkar, Aparajita Bera and Kalimuddin Khan}

Department of Paediatrics, Chittaranjan Seva Sadan College of Obstetrics Gynecology and Child Health, Mukherjee Road, Kolkata, India

\section{Correspondence: \\ Suman Sarkar \\ Department of Paediatrics \\ Chittaranjan Seva Sadan College of \\ Obstetrics Gynecology and Child Health, \\ 37 S P Mukherjee Road, \\ Kolkata-700026, India. \\ Email: dr.sumansarkar@gmail.com}

DOI:10.3126/jnps.v39i2.26964

Submitted on: 2019-12-30

Accepted on: 2020-03-28

Acknowledgements: Sincere gratitude to all parents who have participated in the study and to the Principal and Medical Superintendent cum Vice Principal, Chittaranjan Seva Sadan College of Obstetrics Gynecology and Child Health, Kolkata, India.

Funding: Nil

Conflict of Interest: None declared

Permission form IRB: Not submitted

To cite this article: Birua S, Sarkar S, Bera A, Khan K. Clinico-Demographic Profile of Febrile Seizure and Its Association With Iron Deficiency. J Nepal Paediatr Soc. 2019;39(2):72-8.

\section{ABSTRACT}

Introduction: Febrile seizure (FS) is recognised as the most frequent type of seizure in children (age six months to five years). This observational study was conducted in our hospital to assess any possible association of febrile convulsion with iron deficiency anaemia (IDA) and to see the incidence of iron deficiency in six months to five years old children.

Methods: Eighty eight Simple febrile seizure patients of age six months to five years fulfilled the inclusion criteria and were enrolled between April 2018-March 2019. A pre-designed proforma including detailed history, physical examinations, systemic examinations and relevant investigations were filled-up.

Results: Eighty eight subjects with FS were studied. Occurrence of IDA was $67.04 \%$ among them. Age was significantly associated with haemoglobin $(\mathrm{Hb} \%)(\mathrm{p}$-value $=0.000)$, severity of anaemia ( $\mathrm{p}$-value $=0.000)$, mean corpuscular volume $(\mathrm{MCV})(\mathrm{p}$-value $=0.000)$, mean corpuscular haemoglobin $(\mathrm{MCH})(\mathrm{p}$-value $=0.000)$, mean corpuscular haemoglobin concentration $(\mathrm{MCHC})(\mathrm{p}$-value $=0.000)$ and serum ferritin $(\mathrm{p}$-value $=0.000)$. However, no significant association between $\mathrm{Hb} \%$ and gender was found ( $\mathrm{p}$-value $=0.890$ ).

Conclusions: Considering the clinico-demographic context of the present study and extent of anxiety and worries of parents of FS children, it is imperative to initiate FS prevention and control programme. Nearly two-third of study subjects had significant low serum ferritin indicating association of simple febrile seizure with IDA. However, prevalence of IDA as a risk factor for FS needs to be studied on adequate and representative sample so that iron supplementation could be started as an inbuilt strategy of simple febrile seizure management.

Key words: ferritin; haemoglobin; $\mathrm{MCH}$; $\mathrm{MCHC}$; MCV

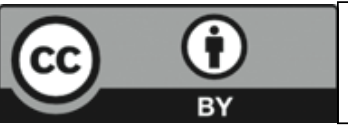

This work is licensed under creative common attribution 3.0 license 


\section{INTRODUCTION}

Febrile seizure (FS) is recognised as the most common neurologic disorder and the most frequent type of seizure in children. It is defined as "a seizure occurring in febrile children between the ages of six to 60 months who do not have an intracranial infection, metabolic disturbance, or history of afebrile seizure" by American Academy of Paediatrics (AAP) (2008). ${ }^{1}$ Although, it has good outcomes without any clinical consequences, it still has a strong possibility of epilepsy in future ${ }^{2}$, as well as rate of recurrence is $30 \%$ and $50 \%$ after the first and the second occurrences respectively ${ }^{3}$ so, there is need to identify correctable risk factors to reduce the prevalence of FS and hence, of epilepsy and convulsion. ${ }^{4,5}$

The overlapping of age for peak incidence of FS (i.e. from 14 to 18 months of age) with that of iron deficiency anaemia (i.e. from six to 24 months of age) suggests possible association between them. ${ }^{6}$ Iron is an important micronutrient for almost all the cells in human body and acts as a co-factor for several enzymes necessary for neurochemical reactions $^{7,8}$, myelin formation ${ }^{9}$ and brain energy metabolism. ${ }^{10}$ Thus its deficiency leads to defective myelination, metabolism of mono-amine oxidase and aldehyde oxidase, as well as synthesis of tyrosine and tryptophan hydroxylase which are essential for synthesis and release of neurotransmitters like serotonin, dopamine and gamma-amino butyric acid (GABA) $)^{11,12}$ which in turn are responsible for change in the amplitude and the threshold of neurons excitation. ${ }^{13}$

Therefore, we determined to study the relationship between prevalence of iron deficiency anaemia (IDA) and incidence of FS among children of age ranging from six months to five years in India. The incidence of FS in India is similar to western figures. ${ }^{14,15}$ The National Family Health Survey-3 (NFHS-3) data states that around 80 per cent children under three years of age have anaemia in India. Hence, we conducted the present observational study in our centre and tried to increase the strength of evidence regarding iron deficiency as a risk factor for febrile seizure because it is evident that iron deficiency anaemia is correctable and remediable condition ${ }^{16}$ and thus, incidence of FS could be decreased by treating nutritional anaemia with diet and iron supplements.

\section{METHODS}

Six months to five years old children with FS brought to our centre and treated in paediatric OPD or admitted in indoor paediatric department depending upon the general condition, were candidates for the study. Emergency treatment was given to stabilise the patient. This observational study was approved by institutional ethical committee and the consent was obtained from parents of each patient who fulfilled the criteria of simple FS before enrolment in the study. Detailed history (demographic data, seizure details, nature of febrile illness including the duration of fever within 24 hours of seizure and other details such as family history of febrile seizures/epilepsy and history of neurodevelopmental problems, temperature at admission, and nutritional status) were recorded. Physical examination including a thorough neurological examination was done. Venous blood sample was collected and sent to the pathology department for investigations. IDA was diagnosed on the basis of the following investigations Haemoglobin ( $\mathrm{Hb} \%)$, peripheral blood smear, mean corpuscular volume (MCV), mean corpuscular haemoglobin $(\mathrm{MCH})$, mean corpuscular haemoglobin concentration (MCHC), red cell distribution width (RDW), serum ferritin and total iron binding capacity (TIBC). $\mathrm{Hb} \%, \mathrm{MCH}, \mathrm{MCV}$, MCHC, RDW and TIBC were measured using automated analyser whereas ferritin by electrochemiluminescence immunoassay method and peripheral blood smear was examined under microscope to look for microcytosis and hypochromia. Equipment used were: analog mercury thermometer (Hicks) for temperature (in degree Fahrenheit), non-stretchable measuring tape (cross tape method) for head circumference, weighing machine based on spring balance (pan type for infants and platform type for children greater than one year age) for weight, infantometer for length and stadiometer for height measurement along with sysmex XP-100 haematology analyser for complete haemogram and ERBA EM-200 for TIBC analysis. 
We considered iron deficiency anaemia in a child if $\mathrm{Hb} \%<11 \mathrm{~g} / \mathrm{dL} ; \mathrm{MCV}, \mathrm{MCH}$ and $\mathrm{MCHC}<-2 \mathrm{SD}$ and ferritin $<30 \mathrm{ng} / \mathrm{dL}$ as per age (according to WHO) for six months to four years 11 months and similarly, $\mathrm{Hb} \%<11.5 \mathrm{~g} / \mathrm{dL}, \mathrm{MCV}, \mathrm{MCH}, \mathrm{MCHC}<$ - $2 \mathrm{SD}$ and ferritin $<15 \mathrm{ng} / \mathrm{dL}$ as per age (according to WHO) for $\geq$ four years 11 months old child. $\mathrm{MCHC}, \mathrm{MCH}, \mathrm{MCV}$, and peripheral blood smear were used to rule out other causes of anaemia. In the present study, normal ferritin level was considered when it was $>30 \mathrm{ng} / \mathrm{dL}$ for healthy children and reduced if $<30 \mathrm{ng} / \mathrm{dL}$ for children with infection.

All relevant data of 88 patients with FS were compiled using Microsoft Excel sheet version 2016 and analysed using SPSS version 22.0 (SPSS Inc. Chicago, Illinois, USA). Frequency (\%) for different variables were calculated. Categorical variables were analysed using Chi-square test as applicable for statistical association and inference. Correlation was considered statistically significant with p-value $<0.05$.

\section{RESULTS}

Our results mainly showing general characteristics of study subjects $(\mathrm{N}=88)$ (Table 1$)$, with their distribution according to severity of anaemia (Table 2), MCV, MCH and MCHC values (Table 3) and ferritin level (Table 4) in different age groups.

Here, we found that the incidence of FS decreased with increasing age where majority of children $(68.2 \%)$ belonged to the age group six months to one year 11 months followed by the age group $>$ one year 11 months to four years 11 months (29.5\%) (Table 1). Mean age of involved children was 20.58 months with standard deviation of 14.03 months.

The percentage of female patients involved was less $(46.59 \%)$ than that of male patients $(53.40 \%)$ (Table 1). Male to female ratio was 1.14:1. Most of children were suffering from moderate anaemia (56.81\%), mild anaemia was found in $17.04 \%$ of enrolled children and none of them had severe anaemia (Table 2).

The values of MCV, MCH and $\mathrm{MCHC}<-2 \mathrm{SD}$ were found in $59(67.04 \%), 68(77.27 \%)$ and 65
Table 1. General characteristics of study subjects

\begin{tabular}{|c|c|c|c|}
\hline \multicolumn{2}{|c|}{ Variables } & \multirow{2}{*}{$\begin{array}{r}\text { No } \\
60\end{array}$} & \multirow{2}{*}{$\begin{array}{l}\text { \% } \\
68.2\end{array}$} \\
\hline Age & $6 \mathrm{~m}-1 \mathrm{yr} 11 \mathrm{~m}$ & & \\
\hline & $>1 \mathrm{yr} 11 \mathrm{~m}-4 \mathrm{yr} 11 \mathrm{~m}$ & 26 & 29.5 \\
\hline & $>4 \mathrm{yr} 11 \mathrm{~m}$ & 2 & 2.3 \\
\hline \multirow[t]{2}{*}{ Sex } & Female & 41 & 46.59 \\
\hline & Male & 47 & 53.40 \\
\hline \multirow{3}{*}{$\begin{array}{l}\text { Temperature } \\
\text { within } 24 \mathrm{hr} \\
\text { of seizure }\end{array}$} & $>99-100^{\circ} \mathrm{F}$ & 0 & 0 \\
\hline & $>100-101^{\circ} \mathrm{F}$ & 63 & 71.59 \\
\hline & $>101-102^{\circ} \mathrm{F}$ & 25 & 28.40 \\
\hline \multirow{2}{*}{$\begin{array}{l}\text { Duration of } \\
\text { seizure } \\
\text { (in min) }\end{array}$} & $<5$ & 25 & 28.40 \\
\hline & $\geq 5$ & 63 & 71.59 \\
\hline \multirow{3}{*}{$\begin{array}{l}\text { Total no. of } \\
\text { seizure (in } \\
\text { life) at } \\
\text { presentation }\end{array}$} & 1st Episode & 72 & 81.8 \\
\hline & 2nd Episode & 13 & 14.8 \\
\hline & $>$ 2nd Episode & 3 & 3.4 \\
\hline \multirow{2}{*}{$\begin{array}{l}\text { Family } \\
\text { history }\end{array}$} & No & 39 & 44.31 \\
\hline & Yes & 49 & 55.68 \\
\hline \multirow[t]{2}{*}{ Anaemia } & Absent & 23 & 26.13 \\
\hline & Present & 65 & 73.86 \\
\hline
\end{tabular}

$(73.86 \%)$ patients respectively and majority of study subjects belonging to age six months to one year 11 months had low values of red cell indices \{value of $\mathrm{MCV}, \mathrm{MCH}$ and $\mathrm{MCHC}<-2$ SD were 46 (52.3\%), 51 (58.0\%) and 48 (54.5\%) respectively\} (Table 3 ). Nearly two-third (67.04\%) patients had low ferritin level including 58 patients of age $<$ five years (Table 4 ).

Age was significantly associated with $\mathrm{Hb} \%$ (pvalue $=0.000)$, severity of anaemia ( $\mathrm{p}$-value $=$ $0.000)$ (Table 2), MCV (p-value $=0.000), \mathrm{MCH}(\mathrm{p}-$ value $=0.000)$, MCHC $(p$-value $=0.000)($ Table 3$)$ and serum ferritin $(\mathrm{p}$-value $=0.000)($ Table 4$)$. But no significant association was found between $\mathrm{Hb} \%$ and gender $(\mathrm{p}$-value $=0.890)$.

\section{DISCUSSION}

Several risk factors for FS in children have been described in literatures and one of those risk factors is iron deficiency. ${ }^{5,17,18}$ In past several decades, many studies have been conducted to establish a 
Table 2. Distribution of study subjects based on severity of anaemia in different age

\begin{tabular}{|c|c|c|c|c|c|}
\hline Age & & Anac & mia & & Total \\
\hline $\begin{array}{l}6 \text { months to } 4 \text { yr } \\
11 \text { months }\end{array}$ & $\begin{array}{l}\text { No anaemia } \\
(\mathrm{Hb} \% \geq 11 \mathrm{~g} / \mathrm{dL})\end{array}$ & $\begin{array}{l}\text { Mild anaemia } \\
(\text { Hb\%10 - 10.9 g/dL) }\end{array}$ & $\begin{array}{l}\text { Moderate anaemia } \\
(\mathrm{Hb} \% 7-9.9 \mathrm{~g} / \mathrm{dL})\end{array}$ & $\begin{array}{l}\text { Severe anaemia } \\
(\mathrm{Hb} \%<7 \mathrm{~g} / \mathrm{dL})\end{array}$ & \\
\hline Frequency & 23 & 13 & 50 & 0 & 86 \\
\hline Percentage & 26.74 & 15.11 & 58.13 & 0 & 100 \\
\hline $\begin{array}{l}>4 \text { yr } 11 \text { months } \\
\text { to } 5 \text { years }\end{array}$ & $\begin{array}{l}\text { No anaemia } \\
(\mathrm{Hb} \% \geq 11.5 \mathrm{~g} / \mathrm{dL})\end{array}$ & $\begin{array}{l}\text { Mild anaemia } \\
(\mathrm{Hb} \% 11-11.4 \mathrm{~g} / \mathrm{dL})\end{array}$ & $\begin{array}{l}\text { Moderate anaemia } \\
(\mathrm{Hb} \% 8-10.9 \mathrm{~g} / \mathrm{dL})\end{array}$ & $\begin{array}{l}\text { Severe anaemia } \\
(\mathrm{Hb} \%<8 \mathrm{~g} / \mathrm{dL})\end{array}$ & \\
\hline Frequency & 0 & 2 & 0 & 0 & 2 \\
\hline Percentage & 0 & 100 & 0 & 0 & 100 \\
\hline
\end{tabular}

definite correlation between them and to stamp IDA as a risk factor for FS among under five years old children. Here, in the present study, we considered the hypothesis of positive relationship between FS and IDA. So, we worked in line of this hypothesis to make a conclusion whether really IDA would be a risk factor for FS or would disapprove our notion. In order to find out any possible association between FS and IDA, this observational study was undertaken in our tertiary care hospital after enrolling 88 patients and it has been found that IDA increases incidence of FS in six months to five years old children.
Majority of the study subjects had experienced the first FS in one year to one year 11 months age in our study. We found that with advancing age, prevalence of FS was decreasing after four years 11 months age, supported by Hesdorffer and Sugai where authors also reported lower incidence before six months or after three years age and concluded that the incidence of FS decreases markedly after four years of age and rarely occurs in children older than seven years of age $\mathrm{e}^{19,20}$ and the peak incidence at around 18 months of age. Thus, age plays an important role in the susceptibility of FS, but the risk of recurrence of seizure declines with age of

Table 3. Distribution of study subjects based on $\mathrm{MCV}, \mathrm{MCH}$ and $\mathrm{MCHC}$ values in different age group

\begin{tabular}{|c|c|c|c|c|c|c|c|}
\hline Age & \multicolumn{2}{|c|}{6 months to 1 yr 11 months } & \multicolumn{2}{|c|}{ yr to 4 yr 11 months } & \multicolumn{2}{|c|}{$5 \mathrm{yr}$} & \multirow[t]{2}{*}{ Total } \\
\hline $\operatorname{MCV}(\mathbf{f} / L)$ & $<67(<-2 S D)$ & $\geq 67(\geq-2 S D)$ & $<73(<-2 S D)$ & $\geq 73(\geq-2 S D)$ & $<74(<-2$ SD) & $\geq 74(\geq-2 S D)$ & \\
\hline Frequency & 46 & 14 & 12 & 14 & 1 & 1 & 88 \\
\hline Percentage & 52.3 & 15.9 & 13.64 & 15.9 & 1.14 & 1.14 & 100 \\
\hline & \multicolumn{7}{|c|}{$X^{2}=1.760 E 2 ; d f=10 ; P=0.000$} \\
\hline MCH (pg) & $<22(<-2$ SD $)$ & $\geq 22(\geq-2 S D)$ & $<25(<-2 S D)$ & $\geq 25(\geq-2 S D)$ & $<25(<-2$ SD $)$ & $\geq 25(\geq-2 S D)$ & \\
\hline Frequency & 51 & 9 & 16 & 10 & 1 & 1 & 88 \\
\hline \multirow[t]{2}{*}{ Percentage } & 58.0 & 10.2 & 18.2 & 11.4 & 1.14 & 1.14 & 100 \\
\hline & \multicolumn{7}{|c|}{$X^{2}=88.326 ; d f=6 ; P=0.000$} \\
\hline $\begin{array}{l}\text { MCHC } \\
(\mathrm{g} / \mathrm{L})\end{array}$ & $<32(<-2$ SD) & $\geq 32(\geq-2 S D)$ & $<32(<-2$ SD $)$ & $\geq 32(\geq-2 S D)$ & $<32(<-2$ SD) & $\geq 32(\geq-2 S D)$ & \\
\hline Frequency & 48 & 12 & 16 & 9 & 1 & 1 & 88 \\
\hline \multirow[t]{2}{*}{ Percentage } & 54.5 & 13.6 & 18.2 & 10.2 & 1.14 & 1.14 & 100 \\
\hline & \multicolumn{7}{|c|}{$X^{2}=1.712 E 2 ; d f=10 ; P=0.000$} \\
\hline
\end{tabular}


Table 4. Distribution of study subjects based on ferritin level in different age group

\begin{tabular}{|lrrrr|}
\hline Age & $\begin{array}{c}\text { Ferritin } \\
(\mathbf{n g} / \mathbf{d L})\end{array}$ & No. & Percentage & $\begin{array}{c}\text { Test of } \\
\text { significance }\end{array}$ \\
\hline$<5 \mathrm{yr}$ & $<30$ & 58 & 65.9 & \\
& $\geq 30$ & 28 & 31.8 & \\
$\geq 5 \mathrm{yr}$ & $<15$ & 1 & 1.14 & $\mathrm{X}^{2}=88.000$ \\
& $\geq 15$ & 1 & 1.14 & $\mathrm{p}=0.000$ \\
Total & & 88 & 100 & \\
\hline
\end{tabular}

growing child. ${ }^{21}$ Literature shows that approximately $6-15 \%$ of children can have FS after four years, and onset after six years is unusual. Regardless of the population, most of the data support the unique age specificity of the maturing brain's sensitivity to fever. Although the mechanism of this increased susceptibility is unclear, animal models suggest that there is enhanced neuronal excitability during the normal brain maturation. ${ }^{22}$ So, this may be a cause that lead to $\mathrm{FS}$ in a specific age group.

IDA is one of the most common nutrition related problems in the world. In developing countries $46-66 \%$ of under five years old children are anaemic. In India as per The National Family Health Survey-3 (NFHS-3), 70\% of under five years old children are anaemic. In the present study, we tried to determine the iron status with the help of $\mathrm{Hb} \%, \mathrm{MCV}, \mathrm{MCH}, \mathrm{MCHC}$ and ferritin level as overlapping of age for peak incidence of FS (i.e. from 14 to 18 months of age) with that of IDA (i.e. from six to 24 months of age) indicates association between them. ${ }^{8}$ We found that $73.86 \%$ of study subjects were anaemic while that of $26.13 \%$ were non-anaemic according to $\mathrm{Hb} \%$ level as per WHO guideline. The value of $\mathrm{MCV}, \mathrm{MCH}$ and $\mathrm{MCHC}<-$ 2 SD were found in $67.04 \%, 77.27 \%$ and $73.86 \%$ study subjects respectively and serum ferritin was also low. Age was significantly associated with $\mathrm{Hb}$ $\%(\mathrm{p}$-value $=0.000)$, severity of anaemia $(\mathrm{p}$-value $=$ $0.000), \operatorname{MCV}(p-$ value $=0.000), \operatorname{MCH}(p-$ value $=$ $0.000), \mathrm{MCHC}(\mathrm{p}$-value $=0.000)$ and serum ferritin $(\mathrm{p}$-value $=0.000)$. No significant association between $\mathrm{Hb} \%$ and gender was found ( $\mathrm{p}$-value = 0.890). Statistically, the results of present study were consistent with findings of the study conducted by Piscane ${ }^{17}$ and Kumari PL. ${ }^{18}$ In contrary, Kobrinsky ${ }^{23}$ in Fargo, reported higher $\mathrm{Hb} \%$ and $\mathrm{MCV}$ values among patients with $\mathrm{FS}$. Bidabadi E et al. ${ }^{24}$, Daoud AS et al. ${ }^{4}$ and Vaswani RK et al. ${ }^{25}$ also found higher $\mathrm{Hb} \%, \mathrm{MCV}, \mathrm{MCH}$, and $\mathrm{MCHC}$ among cases than controls and were unable to establish any significant difference between the two groups statistically.

We found that two-third of the study subjects had lower ferritin level. This result showed similarity with studies done by Daoud AS et al. ${ }^{4}$, Piscane A et al. ${ }^{17}$, Moeman A et al. ${ }^{26}$ and Fallah R et al. ${ }^{27}$ where the mean plasma ferritin level in the FS group was lower than the control group and they found serum ferritin to be statistically correlating with FS.

However, there are few limitations of the present study including inability to rule out some confounding factors causing IDA like lead poisoning, short period of study, and as study was conducted in a single tertiary health care centre, it does not represent the whole population.

\section{CONCLUSIONS}

On the basis of results of the present study, following conclusions were drawn: FS has slight male predominance over female, most of the subjects $(71.59 \%)$ had fever $>100-101^{\circ} \mathrm{F}$ within 24 hours of seizure, short duration (not $>15$ minutes) of seizure, as high as three-fourth $(71.59 \%)$ subjects had seizure for $\geq$ five minutes but not more than 15 minutes duration, subjects with the first episode of FS were found in majority of cases, positive family history was also present in more than half of the study subjects, prevalence of FS was decreasing with advancing age and rising body temperature before or after febrile seizure was not significantly affected by age and gender. Nearly three-fourth of study population were found anaemic and it was significantly correlated with age but not with gender. Prevalence of moderate type of anaemia was observed in around two-third subjects belonged to age group six months to one year 11 months. Significant association between age of study subjects and red cell indices as well as low ferritin in anaemic children with FS were noticed. However, no significant association between $\mathrm{Hb} \%$ 
and gender of different age groups in children with FS was found. So, considering the clinicodemographic context of the present study and extent of anxiety and worries of parents of FS children, it is imperative to initiate FS prevention and control programme. But, prevalence of IDA as a risk factor for FS needs to be studied on adequate and representative sample and therefore, there is need for undertaking effective trial with long term follow-up to demonstrate effectiveness of iron supplementation in FS in community involving larger population, so that iron supplementation could be started as an inbuilt strategy of FS management.

\section{REFERENCES}

1. Steering Committee on Quality Improvement and Management, Subcommittee on Febrile Seizures American Academy of Paediatrics. Febrile seizures: clinical practice guideline for the long-term management of the child with simple febrile seizures. Paediatrics. 2008;121(6):1281-6.DOI: https://doi.org/10.1542/peds.2008-0939

2. Van der Berg BJ, Yerushalmy J. Studies on convulsive disorders in young children. I. Incidence of febrile and non febrile convulsions by age and other factors. Paediatr Res. 1969;3(4):298-304.DOI: 10.1203/00006450-196907000-00005.

3. Jones T, Jacobsen SJ. Childhood febrile seizures:overview and implications. Int J Med Sci. 2007;4(2):110-4. DOI: 10.7150/ijms.4.110

4. Daoud AS, Batieha A, Abu-Ekteish F, Gharaibeh N, Ajlouni S, Hijazi S. Iron Status: A Possible Risk Factor for the First Febrile Seizure. Epilepsia. 2002;43(7):740-3. DOI:10.1046/j.1528-1157.2002.32501.X

5. Hartfield DS, Tan J, Yager JY, Rosychuk RJ, Spady D, Haines C, et al. The Association between Iron Deficiency and Febrile Seizures in Childhood. Clin Pediatr (Phila). 2009;48(4):420-6. DOI:10.1177/0009922809331800

6. Sherjil A, Saeed Z, ShehzadS, Amjad R. Iron deficiency anaemia-a risk factor for febrile seizures in children. J Ayub Med Coll Abbottabad 2010 Jul-Sep;22(3):71-3. PMID:22338422

7. Beard JL, Erikson KM, Jones BC. Neurobehavioral analysis of developmental iron deficiency in rats. Behav Brain Res. 2002 Aug;134(1-2):517-24. DOI:10.1016/s0166-4328(02)00092-X

8. Rouault TA, Cooperman S. Brain iron metabolism. Semin Pediatr Neurol. 2006 Sep;13(3):142-8. DOI:10.1016/ j.spen.2006.08.002

9. Badaracco ME, Siri MV, Pasquini JM. Oligodendrogenesis: the role of iron, Biofactors. 2010 Mar-Apr;36(2): 98-102. DOI:10.1002/biof.90

10. Erikson KM, Jones BC, Hess EJ, Zhang Q, Beard JL. Iron deficiency decreases dopamine D1 and D2 receptors in rat brain. Pharmacol Biochem Behav. 2001 Jul-Aug;69(3-4):409-18.DOI:10.1016/s0091-3057(01)00563-9

11. Knight M, Ebert J, Parish RA, Berry H, Fogelson MH. Gamma-Aminobutyric acid in CSF of children with febrile seizures. Arch Neurol. 1985 May;42(5):474-5. DOI:10.1001/archneur.1985.04060050076011

12. Heydarian F, Vatankhah H. The role of anemia in first simple febrile seizure in children aged 6 months to 5 years old. Neurosciences (Riyadh). 2012 Jul;17(3):226-9. PMID:22772927

13. Beard J. Iron deficiency alters brain development and functioning. J Nutr 2003;133:146872 S. DOI:10.1093/jn/ 133.5.1468S

14. Hackett R, Hackett L, Bhakta P. Febrile seizures in a South Indian district: Incidence and associations. Dev Med Child Neurol. 1997;39:380-4. DOI:10.1111/j1469-8749.1997.tb07450.x

15. Gourie-Devi M, Gururaj G, Satishchandra P, Subbakrishna DK. Prevalence of neurological disorders in Bangalore, India: A community-based study with a comparison between urban and rural areas. Neuro epidemiology. 2004; 23(6): 261-8. http://doi.org/10.1159/000080090

16. World Health Organisation. Iron deficiency anaemia. Assessment, prevention and control. A Guide for Program Managers. WHO/NHD/013.Geneva.2001. 
17. Pisacane A, Sansone R, Impagliazzo N, Coppola A, Rolando P, D’ApuzzoA, et al. Iron deficiency anaemia and febrile convulsions: Case-control study in children under 2 years. BMJ. 1996 Aug;313:343-4. DOI:10.1136/bmj. 313.7053 .343

18. Kumari PL, Nair MK, Nair SM, Kailas L, Geetha S. Iron deficiency as a risk factor for simple febrile seizures-a case control study. Indian Pediatr. 2012;49:17-9.DOI:10.1007/s13312-012-0008-6

19. Hesdorffer DC, Benn EK, Bagiella E, Bagiella E, Nordli D. Distribution of febrile seizure duration and associations with development. Ann. Neurol. 2011;70:93-100.DOI:10.1002/ana.22368

20. Sugai K. Current management of febrile seizures in Japan: an overview. Brain Dev. 2010;32:64-70. DOI:10.1016/ j.braindev.2009.09.019

21. Berg AT, Shinnar S, Darefsky AS. Predictors of recurrent febrile seizures: A prospective cohort study. Arch Pediatr Adolesc Med. 1997;151:371-8. DOI:10.1001/archpedi.1997.02170410045006

22. Jensen FE, Sanchez RM. Why does the developing brain demonstrate heightened susceptibility to febrile and other provoked seizures. In :Baram TZ, Shinnar S, eds. Febrile seizures. San Diego: Academic Press, 2002:153-68. DOI: 10.1016/B978-012078141-6/50013-5

23. Kobrinsky NL, Yager JY, Cheang MS, Yatscoff RW, Tenenbein M. Does iron deficiency raise the seizure threshold? J Child Neurol. 1995 Mar;10(2):105-9. DOI:10.1177/088307389501000207

24. Bidabadi E, Mashouf M. Association between Iron Deficiency Anaemia and First Febrile Convulsion: A Casecontrol Study. Seizure. 2009 Jun;18(5):347-51. DOI:10.1016/j.seizure.2009.01.008

25. Vaswani RK, Dharaskar PG, Kulkarni S, Ghosh K. Iron deficiency as a risk factor for first febrile seizure. Indian Pediatr. 2010;47(5):437-9. DOI:10.1007/s13312-010-0080-8

26. Momen A, Nikfar R, Karimi B. Evaluation of Iron Status in 9-month to 5-year-old Children with Febrile Seizures: A Case-control Study in the South West of Iran. Iran J Child Neurol 2010;4(2):45-50. DOI:https://doi.org/10.22037/ ijcn.v4i2.1870

27. Fallah R, Tirandazi B, Ferdosian F, Fadavi N. Iron deficiency and iron deficiency anaemia in children with first attack of seizure and on healthy control group: A comparative study. Iran J Child Neurol. 2014; 8(3):18-23. PMID: 25143769, PMCID: PMC4135276 